In Memoriam

\title{
JĀNIS GUNTIS BĒRZIN̦Š (19 JANUARY 1936 - 14 DECEMBER 2017), LATVIAN PHYSICIST
}

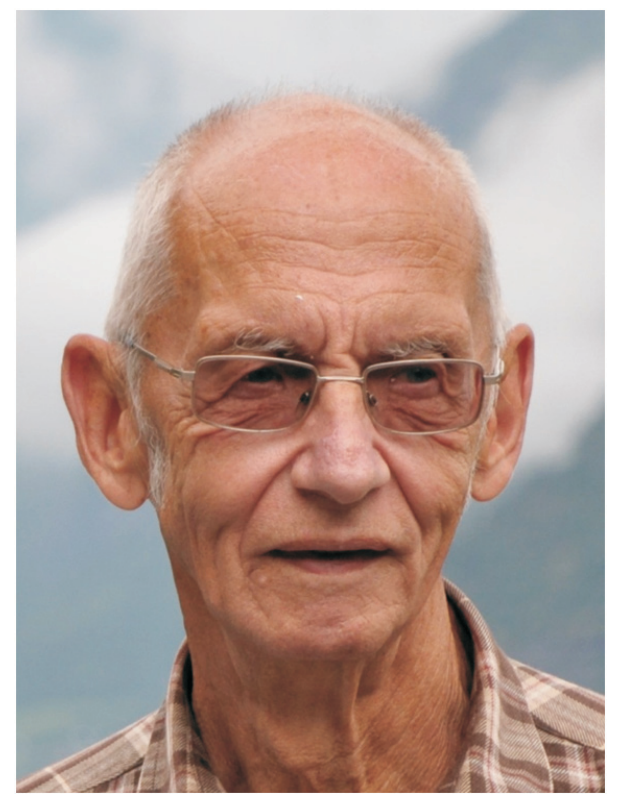

Dr. habil. phys. Jānis Guntis Bērziñš was a full member of the Latvian Academy of Sciences since 2004 (corresponding member since 1999) and one of the leading nuclear physicists in Latvia. All his long working life spanning nearly six decades was devoted to the nuclear physics experiments and study of nuclear structures.

As a boy, Jānis was keen on solving various technical problems and already during his high school studies in Valmiera he understood that he was going to study physics. During his studies, the University of Latvia was offering a new major in nuclear physics to develop researchers for then future Nuclear Research Center in Salaspils. J. Bērziņš was in the first cohort of students graduating in 1959 and starting straight at the Nuclear Research Center, where he worked from its first until the last day assuming the role of director at the end.

J. Bērzinšs started work in the Laboratory of Nuclear Spectroscopy under the lead scientist in the field $\mathrm{Dr}$. phys. Pēteris Prokofjevs and after the retirement of P. Prokofjevs was the head of the laboratory for years. There were lots of things to learn and develop in the newly opened research center - complex scientific research machines had to be built, research methods in nuclear spectroscopy developed, results analysed and reported. J. Bērziņš was very active in all of these core scientific activities. Collaboration with other leading international research centres was essential for science and had opened opportunities for him to work in
Gatchina, Dresden, Munich, Karlsruhe, and Grenoble. Long-term collaboration had turned in life-long friendship with Profs. Helmut Rotter, Rosendorf-Dresden and Till von Egidy, Technical University of Munich.

The Laboratory of Nuclear Spectroscopy joined the Institute of Solid State Physics, University of Latvia, after the close of the Nuclear Research Center in Salaspils and became the Laboratory of Radiation Physics. Unfortunately, the era of empirical nuclear research in Latvia is over, but this partly is overcome via international cooperation conducting experiments abroad.

J. Bērziņš gained great satisfaction in working for the international research programme Euratom. As a representative from the Latvian Academy of Sciences, he worked with the Consultative Committee for Fusion and Fission since 2000 and became a member of the Scientific and Technical Committee Euratom.

Based on his research on the structure of atomic nuclei, J. Bērzinšs has earned both Dr. phys. and Dr. habil. phys. degrees. He is the author of more than 150 publications. J. Bērziňš was elected as a corresponding member of the Latvian Academy of Sciences in 1999 and as a full member of the Latvian Academy of Sciences in 2004.

Jānis Bērziņš had an inherent, acute sense of civic duty. A vivid example was after the nuclear accident in Chernobyl 
in 1986, when he applied his expertise to form a group of radiation specialists, who had realised the monitoring of nuclear contamination on some food and environment in Latvia.

J. Bērziņš assumed various roles beneficial to society in parallel to his scientific career. As an example, he worked at the council of Salaspils $1^{\text {st }}$ Kindergarten for many years. His contribution was noted by Salaspils city awarding him the title of a Honorary Citizen.
Jānis Bērziņš had a strong family, close friends, and great colleagues. While being completely dedicated to his work, he gave his full love, sense of responsibility, and care to his family and having extra close ties with his family members. Jānis was fortunate to have a close circle of friends for many years with whom he progressed through life, discussed and debated everything possible and on whom he could always completely rely. Jānis Bērzin̄š felt blessed to be part of the Institute of Solid State Physics, where he had numerous great colleagues who keep him in their fond memories.

Mārtiňš Rutkis

\section{JĀNIS GUNTIS BĒRZIN̦Š (1936-2017), FIZIKISS}

Mūžībā aizgājis LZA īstenais loceklis Dr. habil. phys. Jānis Guntis Bērziņš — viens no vadošiem kodolfiziķiem Latvijā. Visu savu darba mūžu gandrīz 60 gadu garumā viṇ̌ ir veltījis kodolfizikas eksperimentiem un kodolu struktūras izpētei.

1959. gadā Jānis Bērziņš pabeidza Latvijas Valsts universitāti un uzsāka darbu LZA Salaspils Kodolreaktorā, kur strādāja no tā pirmās dienas līdz slēgšanai, beigu posmā esot tā direktors. Kodolreaktorā viṇš strādāja izcila zinātnieka Pētera Prokofjeva vadītajā Kodolspektroskopijas laboratorijā un vēlāk pārṇēma šis laboratorijas vadību. Pēc Salaspils Kodolreaktora slēgšanas Kodolspektroskopijas laboratorija pievienojās Latvijas Universitātes Cietvielu fizikas institūtam, kḷūstot par Radiācijas fizikas laboratoriju.

Kopš 2000. gada Jānis Bērziṇš darbojās kā LZA pārstāvis Euratom Fusion un Fission Konsultatīvajās komitejās un bija Euratom Zinātniski tehniskās komitejas loceklis.

Jānis Bērziṇš ir ieguvis fizikas doktora un fizikas habilitētā doktora grādus, viṇš ir autors vairāk kā 150 publikācijām. 1999. gadā Jāni Bērziņu ievēlēja par LZA korespondētājlocekli un 2004. gadā — par LZA īsteno locekli. 